Sylwia Kuźma-Markowska

Uniwersytet Warszawski

Ośrodek Studiów Amerykańskich

\title{
Walka z „babkami" o zdrowie kobiet: medykalizacja przerywania ciąży w Polsce w latach pięćdziesiątych i sześćdziesiątych XX wieku
}

\begin{abstract}
Zarys treści: Artykuł ukazuje ustawę o warunkach dopuszczalności przerywania ciąży z $1956 \mathrm{r}$. jako element walki z „babkarstwem” prowadzonej przez władze oraz przedstawicieli socjalistycznej medycyny. Dążąc do wyeliminowania tradycyjnych, ludowych praktyk medycznych oraz do objęcia zdrowia reprodukcyjnego kobiet naukowym nadzorem medycznym, władze PRL i sprzyjające im środowisko lekarskie oficjalnie ukazywali ustawę z 1956 r. jako prowadzącą do wyeliminowania nielegalnych i nieprofesjonalnych aborcji i dzięki temu chroniącą życie i zdrowie kobiet. Jednocześnie, przerywanie ciąży było ukazywane $\mathrm{w}$ debacie publicznej i w dyskursie medycznym jako skomplikowany zabieg medyczny, do którego zmedykalizowania i spatologizowania dążyli przedstawiciele socjalistycznej medycyny.
\end{abstract}

Słowa kluczowe: aborcja, PRL, „babki”, medykalizacja, medycyna ludowa, medycyna naukowa Keywords: abortion, the Polish People's Republic, granny midwives, medicalisation, folk medicine, scientific medicine

„W celu ochrony zdrowia kobiety przed ujemnymi skutkami zabiegów przerywania ciąży dokonywanych w nieodpowiednich warunkach lub przez osoby nie będące lekarzami”" - tymi słowami zaczynała się ustawa o warunkach dopuszczalności przerywania ciąży uchwalona w kwietniu 1956 r. Wiosną tego samego roku branżowe czasopismo „Służba Zdrowia” podkreślało: „Za koniecznością uregulowania tych ważnych spraw przemawiały fakty: tysiące poronień, dokonywanych w antysanitarnych warunkach, setki ciężkich schorzeń, wypadki śmierci”2. Aspekt medyczny przerywania ciąży i jego wpływ na zdrowie kobiet był stale

\footnotetext{
${ }^{1}$ Warunki dopuszczalności przerywania ciąży, Warszawa 1959, wyd. 2, s. 9.

${ }^{2}$ Ustawa wchodzi w życie, trzeba ją właściwie realizować, „Służba Zdrowia” 1956, nr 20, s. 1.
} 
obecny i mocno podkreślany w dyskusjach toczących się w drugiej połowie lat pięćdziesiątych i na początku lat sześćdziesiątych XX w. Debata prowadzona w tym okresie dotyczyła samej ustawy, powodów jej uchwalenia oraz realizacji zapisów. Medyczny wymiar aborcji stanowił jeden $\mathrm{z}$ istotnych kontekstów zmiany prawnej dotyczącej kwestii reprodukcyjnych w Polsce Ludowej oraz ich praktycznego wymiaru.

Zmiany w zapisach dotyczących przerywania ciąży w latach pięćdziesiątych $\mathrm{XX}$ w. były do tej pory analizowane m.in. w odniesieniu do przemian politycznych w bloku wschodnim w momencie odwilży ${ }^{3}$ czy też jako element kształtowania nowych ról płciowych dla kobiet po okresie stalinizmu ${ }^{4}$. Legalna aborcja miała również pomóc władzom państw Europy Środkowo-Wschodniej w zwiększeniu kobiecej siły roboczej potrzebnej w rozwijających się gospodarkach ${ }^{5}$. Moim celem jest przyjrzenie się wprowadzeniu ustawy o warunkach przerywania ciąży w kontekście walki z „babkarstwem” prowadzonej od lat czterdziestych XX w. przez przedstawicieli socjalistycznej medycyny. Perspektywa ta pozwala wpisać kwestie związane ze zdrowiem reprodukcyjnym kobiet w szerszy kontekst dokonującego się w Polsce Ludowej przejścia od przednowoczesnej do nowoczesnej medycyny.

$\mathrm{W}$ artykule poddam analizie proces medykalizacji przerywania ciąży w Polsce Ludowej, który stanowiły walka z „babkami” o życie i zdrowie kobiet oraz przedstawianie aborcji jako choroby wymagającej nadzoru wykwalifikowanego lekarza specjalisty. Interesować mnie będzie przede wszystkim okres drugiej połowy lat pięćdziesiątych i początek lat sześćdziesiątych XX w., stanowiący czas burzliwych dyskusji na temat przerywania ciąży w środowisku lekarskim i w całym społeczeństwie. Wykorzystując dokumenty wytworzone przez władze państwowe, prasę branżową, periodyki skierowane do kobiet i broszury dotyczące praktyk reprodukcyjnych z przełomu lat pięćdziesiątych i sześćdziesiątych XX w., przyjrzę się zabiegom retorycznym i narracyjnym stosowanym w celu medykalizacji aborcji. Sięgnę także po prasę katolicką, aby poznać podobieństwa i różnice

\footnotetext{
${ }^{3}$ G. Kligman, Polityka obłudy. Kontrola rozrodczości w Rumunii pod rządami Ceausescu, Kraków 2010, s. 74.

${ }^{4}$ M. Fidelis, Kobiety, komunizm i industrializacja w powojennej Polsce, Warszawa 2015, s. 210-222.

${ }^{5}$ E. Zielińska, Between Ideology, Politics, and Common Sense. The Discourse of Reproductive Rights in Poland, w: Reproducing Gender. Politics, Publics, and Everyday Life after Socialism, ed. S. Gal, G. Kligman, Princeton, NJ 2000, s. 26. Eleonora Zielińska poświęciła dwie książki kwestiom prawnym związanym z przerywaniem ciąży, między innymi w PRL: por. eadem, Oceny prawnokarne przerywania ciąży. Studium porównawcze, Warszawa 1986; eadem, Przerywanie ciąży. Warunki legalności w Polsce i na świecie, Warszawa 1990. Na temat kontekstów wprowadzenia ustawy z 1956 r. por. także: G. Miernik, Wokół ustawy aborcyjnej z 1956 r., w: Zdrowie i choroba. Wplyw jakości życia na kulturę w Europie Środkowej, red. A. Barciak, Katowice-Zabrze 2013, s. 348375. Na temat głosów obywateli w sprawie przerywania ciąży w momencie zmiany legislacyjnej w 1956 r. por.: B. Klich-Kluczewska, Rodzina, tabu i komunizm w Polsce 1956-1989, Kraków 2015, s. $245-259$.
} 
w argumentach odnoszących się do walki z „babkarstwem” oraz w narracjach dotyczących zdrowia kobiet używanych przez różne frakcje ideowe środowiska lekarskiego. Poza kręgiem moich zainteresowań znajdą się inne, w tym etyczne, reperkusje ustawy o warunkach przerywania ciąży, czy też istotny wymiar demograficzny wprowadzanych ówcześnie zmian prawnych ${ }^{6}$.

Ustawa o warunkach dopuszczalności przerywania ciąży z 1956 r. może być, jak sądzę, analizowana w kontekście procesu medykalizacji, jakiej od 1945 r. były w Polsce Ludowej poddawane praktyki reprodukcyjne kobiet. Medykalizację definiuję za Adele Clarke i jej współpracowniczkami jako: „procesy, za pośrednictwem których aspekty życia dotychczas leżące poza sferą kompetencji medycyny zaczęły być konstruowane jako problemy medyczne"7. Zachodni badacze medykalizacji podkreślają rolę lekarzy profesjonalistów w obejmowaniu przez medycynę nadzoru nad wydarzeniami i sferami życia człowieka, które wcześniej uważano za „naturalne” bądź leżące w gestii takich dyscyplin jak prawo czy religia. Historycy ukazują medykalizację również jako jeden z elementów rodzenia się i kształtowania społeczeństwa nowoczesnego, przypadających w Europie Zachodniej i Ameryce Północnej na koniec XIX i pierwszą połowę XX w. ${ }^{8}$

Medykalizacja, także w przypadku interesującego mnie zdrowia i życia reprodukcyjnego kobiet, od końca XIX w. postępowała stopniowo również na ziemiach polskich. Wtedy to, podobnie jak w innych krajach zachodniego kręgu kulturowego, kontrolą lekarską starano się obejmować takie praktyki, zjawiska i etapy kobiecego życia reprodukcyjnego jak ciąża, poród czy laktacja9 . Wcześniej stano-

\footnotetext{
${ }^{6} \mathrm{O}$ tym ostatnim pisałam w: S. Kuźma-Markowska, Międzynarodowe aspekty działalności Towarzystwa Świadomego Macierzyństwa w latach 50. i 60. XX w., w: Problem kontroli urodzeń i antykoncepcji. Krytyczno-porównawcza analiza dyskursów, red. B. Płonka-Syroka, A. Szlagowska, Wrocław 2013, s. 271-274. O podstawach radzieckiej polityki demograficznej i populacyjnej i jej realizacji w ZSRR: M. Nakachi, Liberation without Contraception? The Rise of the Abortion Empire and Pronatalism in Socialist and Postsocialist Russia, w: Reproductive States. Global Perspectives on the Invention and Implementation of Population Policy, ed. R. Solinger, M. Nakachi, New York and Oxford 2016, s. 293-299.
}

${ }^{7}$ A. Clarke et al., Biomedicalization. Technocratic Transformation of Health, Illness, and U.S. Biomedicine, w: Biomedicalization, Technoscience, Health, and Illness in the U.S., ed. A. Clarke et al., Durnham 2010, s. 48, cyt. za: A. Kościańska, Płeć, przyjemność i przemoc. Kształtowanie wiedzy eksperckiej o seksualności w Polsce, Warszawa 2014, s. 40.

${ }^{8}$ Ibidem, s. 47.

${ }^{9}$ Por. np. A. Bołdyrew, Matka i dziecko $w$ rodzinie polskiej. Ewolucja modelu życia rodzinnego $w$ latach 1795-1918, Warszawa 2008, s. 48; E. Więckowska, Opieka położnicza w Królestwie Polskim na przełomie XIX i XX w., „Medycyna Nowożytna” 15, 2008, nr 1-2, s. 65-68; S. Kuźma-Markowska, From „Drop of Milk” to „Bureaus for Mothers”. Infant Care and Visions of Medical Motherhood in the 
wiące w większości nienadzorowane, prywatne doświadczenia i traktowane jako „naturalny”, niewymagający interwencji stan, w epoce industrializacji i urbanizacji zaczęto coraz częściej przedstawiać jako potencjalnie patologiczne i wymagające kontroli i opieki wykwalifikowanego specjalisty, w owych czasach przede wszystkim lekarza-mężczyzny.

W historii początków medykalizacji kobiecego doświadczenia reprodukcyjnego na ziemiach polskich zwraca uwagę kilka istotnych kwestii. Po pierwsze, do wybuchu II wojny światowej kontrolą i opieką lekarską zostały objęte praktyki reprodukcyjne tylko niewielkiego procenta Polek, przede wszystkim tych lepiej usytuowanych i pochodzących z elit społecznych. Państwowe, samorządowe i dobroczynne inicjatywy medyczne i lekarskie napotykały wiele przeszkód, przede wszystkim finansowych, lecz także kadrowych i infrastrukturalnych. Przez całe międzywojnie w Polsce doskwierał niedostatek lekarzy oraz placówek medycznych; większość obywateli zaś pozostawała poza systemem profesjonalnej opieki medycznej i nie była objęta ubezpieczeniem społecznym. Wyspecjalizowana i naukowa wiedza lekarska nie była generalnie dostępna dla wszystkich mieszkańców kraju. Braki wykwalifikowanego personelu starano się więc, zwłaszcza w uboższych kręgach, rekompensować usługami felczerów czy znachorów ${ }^{10}$. Zarówno w środowiskach miejskich, jak i wiejskich, kobiety powszechnie korzystały z usług i pomocy „babek” i nieprofesjonalnych akuszerek ${ }^{11}$. Nie rozwinęła się ówcześnie także w Polsce na taką skalę jak w innych krajach, na przykład Niemczech, Wielkiej Brytanii czy Stanach Zjednoczonych ${ }^{12}$ profesja położnika-ginekologa ${ }^{13}$. Tylko na obszarze zaboru pruskiego w XIX w. doszło do wyraźnego wyodrębnienia się tej grupy zawodowej i jej radykalnego odcięcia od „nieregularnych” praktyków medycznych, zajmujących się zdrowiem reprodukcyjnym kobiet ${ }^{14}$. Z kolei w Europie Zachodniej i Ameryce Północnej od

Early 20th Century Polish Part of the Habsburg Empire, w: Medicine Within and Between Habsburg and Ottoman Empires, 18th-19th Centuries, ed. D. Sechel, Bochum 2012, s. 131-148.

${ }^{10}$ E. Więckowska, Lekarze jako grupa zawodowa w II Rzeczypospolitej, Wrocław 2004, passim; W. Piątkowski, Spotkania z inna medycyna, Lublin 1990, s. 46, 54-56.

${ }^{11}$ A. Malarewicz, M. Sola, Położnictwo. Miniona Epoka. Przyczynek do historii położnictwa, „Studia Medyczne" 23, 2011, nr 3, s. 88.

12 J.W. Leavitt, „The Growth of Medical Authority”. Technology and Morals in Turn-of-the-Century Obstetrics, w: Women and Health in America. Historical Readings, ed. J.W. Leavitt, Madison, Wisconsin 1999, s. 636-658; Childbirth. Changing Ideas and Practices in Britain and America 1600 to the Present, t. 2: The Medicalization of Obstetrics. Personnel, Practice, and Instruments, ed. P.K. Wilson, New York and London 1996, passim; C. Usborne, Cultures of Abortion in Weimar Germany, New York and Oxford 2007, s. 64-66.

${ }^{13}$ E. Waszyński, Historia położnictwa i ginekologii w Polsce, Wrocław 2000.

${ }^{14} \mathrm{Na}$ temat ziem polskich znajdujących się pod zaborem pruskim: J. Mysztor, Prawnospołeczne aspekty zabójstw dzieci narodzonych i aborcji na Ślasku w latach 1775-1914, „Roczniki Nauk Prawnych” 24, 2014, nr 4, s. 119-121; na temat Niemiec, por.: C. Usborne, op. cit.; J. Woycke, Birth Control in Germany, 1871-1933, New York and London 1988. 
końca XIX w. praktyki reprodukcyjne żeńskiej części społeczeństwa były obejmowane wiedzą-władzą położników i ginekologów, a dyskurs na temat „naturalnych" wcześniej procesów i zmian zachodzących w kobiecym ciele zmieniał swój charakter: z religijnego na medyczny, stając się elementem biowładzy i zarządzania populacją ${ }^{15}$.

Procesy medykalizacji miały miejsce także $\mathrm{w}$ przypadku zapobiegania i przerywania ciąży. „Sztuczne poronienia” w czasach przednowoczesnych charakteryzowało kilka ważnych dla moich rozważań wyróżników. Po pierwsze, nie zawsze były one uznawane, zwyczajowo i/lub prawnie, za przestępstwo. Na przykład, według obowiązującego $\mathrm{w}$ krajach anglosaskich common law przerwanie ciąży nie stanowiło wykroczenia kryminalnego do momentu poczucia przez kobietę ruchów płodu (quickening), mających zazwyczaj miejsce po ukończeniu pierwszego trymestru ciąży. O (sztucznych) poronieniach mających miejsce w tym okresie myślano w kategoriach "przywracania miesiączki” (bringing back the period) ${ }^{16}$. Angielska badaczka Kate Fisher zwraca uwagę, że co najmniej do okresu międzywojnia wśród kobiet z klasy robotniczej w Wielkiej Brytanii nie istniało ostre rozgraniczenie pomiędzy „byciem w ciąży” $i$ „niebyciem w ciąży” w początkowym okresie po ewentualnym zapłodnieniu. Wiele Angielek (według jednego ze źródeł nawet $60 \%$ mężatek), miało co miesiąc "upewniać się i sprawiać, że okres się pojawia” używając licznych dostępnych na rynku preparatów wczesnoporonnych ${ }^{17}$. Robily tak, nie wiedząc naprawdę, czy są w ciąży, czy też nie. „Przywracanie miesiączki” nie było przez bohaterki Fisher postrzegane jako konflikt moralny; budziło tylko obawy ze względu na ewentualne niebezpieczeństwo dla zdrowia. Problematyczne etycznie stawało się dopiero po poczuciu ruchów płodu, kiedy to przyjmowane środki mogły doprowadzić do jego deformacji ${ }^{18}$.

Postrzeganie aborcji w kategoriach „przerywania miesiączki” miało miejsce również na ziemiach polskich; opisują je dla okresu międzywojnia m.in. Magdalena

\footnotetext{
${ }^{15}$ Badacze procesów medykalizacji odwołują się zwykle do koncepcji M. Foucault, pokazując jak profesjonalna i naukowa medycyna stawała się jedną z gałęzi wiedzy-władzy: por. np. D. Lupton, Foucault and the Medicalization Critique, w: Foucault, Health, and Medicine, ed. A.R. Petersen, R. Bunton, London and New York 1997, s. 94-112; Reassessing Foucault. Power, Medicine, and the Body, ed. C. Jones, R. Porter, New York and London 1994; K.K. Barker, A Ship Upon a Stormy Sea. The Medicalization of Pregnancy, „Social Science and Medicine” 47, 1998, nr 8, s. 1067-1076; B.S. Turner, Medical Power and Social Knowledge, London 1995; J. Sawicki, Disciplining Foucault. Feminism, Power, and the Body, New York and London 1996, s. 67-94.

16 J.M. Riddle, Eve's Herbs. A History of Contraception and Abortion in the West, Cambridge and London 1997, s. 3, 94-95, 165-166; A. McLaren, A History of Contraception. From Antiquity to the Present, Oxford 1990, s. 216; L. Reagan, When Abortion Was a Crime. Women, Medicine, and Law in the United States, Chapel Hill 1997, s. 8-10.

${ }^{17}$ K. Fisher, Birth Control, Sex, and Marriage in Britain 1918-1960, Oxford and New York 2008, s. 159.

${ }^{18}$ Ibidem, s. 159-160.
} 
Gawin i Marta Kurkowska ${ }^{19}$. Gawin podkreśla, że przekonanie o wczesnej ciąży, będącej zakrzepłą krwią menstruacyjną, utrzymywało się szczególnie wśród niższych warstw społecznych ${ }^{20}$. Tradycyjne, przednowoczesne rozumienie aborcji było powszechne w Polsce jeszcze w latach pięćdziesiątych XX w., o czym świadczy debata tocząca się w trakcie uchwalania ustawy o warunkach dopuszczalności przerywania ciąży i następująca po niej dyskusja publiczna. W kwietniu $1956 \mathrm{r}$. argument o ruchach płodu pojawił się na ustach posłanki reprezentującej klasy niższe, wywodzącej się ze środowiska robotniczego Łodzi. Niewykształcona prządka i przodownica pracy, a w nowym ustroju dyrektorka fabryki Wanda Gościmińska, zwróciła się do posłów m.in. tymi słowami: „Czy to jest grzech, jeżeli w początku, gdy zalążek jest jeszcze nieruchomy i nieżywy, straci się go. To jest grzech? To jest obłuda, kłamstwo i fałsz"21. Według cytującej Gościmińską historyczki Małgorzaty Fidelis posłanka odwoływała się do powszechnie panującego, tradycyjnego "przekonania, że płód nie jest żywy, dopóki matka nie poczuje jego ruchów"22.

O powszechnym pośród kobiet poglądzie, że ciąża w czasie pierwszych miesięcy stanowi „jaką̧́ bezkształtną masę skrzepów krwi”"23 pisali w drugiej połowie lat pięćdziesiątych XX w. zarówno publicyści katoliccy, jak i lekarze związani ze wspieranym przez władze Towarzystwem Świadomego Macierzyństwa. Przednowoczesne rozumienie procesu zapłodnienia jako „zatrzymania się menstruacji” skłaniało Polki do sięgania po zastrzyki i proszki, mające przywrócić „prawidłowy cykl miesięczny”24. „Uregulować” kobiecy organizm mogło również czyszczenie macicy, postrzegane według jednego z katolickich autorów przez „ogół społeczeństwa” jako „niewinny, kilkuminutowy, jak niektórzy określają - «kosmetyczny» zabieg" 25 . Z tradycyjnymi, według nich nienaukowymi poglądami na temat przerywania ciąży walczyły obie strony debaty, starając się uświadomić kobietom wagę etyczną zabiegu i/lub potencjalnie niebezpieczny wpływ na zdrowie.

Dla przednowoczesnego zjawiska aborcji istotna jest jeszcze jedna cecha: zwyczajowy brak medykalizacji samego zabiegu. Dążąc w przeszłości do „przywrócenia

${ }^{19}$ M. Gawin, Planowanie rodziny - hasła i rzeczywistość, w: Równe prawa i nierówne szanse. Kobiety w Polsce międzywojennej, red. A. Żarnowska, A. Szwarc, Warszawa 2000, s. 226; M. Kurkowska, „Fabrykantki aniołków”. O problemie aborcji w Polsce w latach 1878-1939, „Arcana” 19, 1998, nr 1, s. $157-166$.

${ }^{20}$ M. Gawin, op. cit., s. 226.

${ }^{21}$ Sejm PRL. Kadencja I - Sesja VIII. Sprawozdanie stenograficzne z VIII sesji Sejmu Polskiej Rzeczpospolitej Ludowej $w$ dniach od 23 do 28 kwietnia, Warszawa 1956, s. 496; cyt. za M. Fidelis, op. cit., s. 217.

${ }^{22}$ Ibidem, s. 217-218.

${ }^{23}$ B. i J. Matyjkowie, Oddziaływanie lekarskie $w$ dziedzinie ratowania życia, „Ateneum Kapłańskie” 56, 1958, z. 2(295), s. 283.

${ }^{24}$ T. Majle, Co każde małżeństwo wiedzieć powinno o zapobieganiu ciąży, Warszawa 1958, s. 26.

${ }^{25}$ Stanowisko lekarza katolika wobec problemu niszczenia ciąży, „Ateneum Kapłańskie” 55, 1957, z. 2(292), s. 240. 
miesiączki” używano przede wszystkim dostępnych, nierzadko wręcz „domowych” produktów i sposobów, takich jak preparaty ziołowe (np. odpowiednio spreparowany sporysz czy mięta), środki chemiczne (esencja octowa, amoniak), metale ciężkie (np. rtęć). Kobiety starały się przerwać ciążę za pomocą forsownego wysiłku fizycznego i sposobami mechanicznymi, przede wszystkim wprowadzając ostro zakończone przedmioty do macicy. W sprzedaży, także obwoźnej, były dostępne różnorodne, $\mathrm{w}$ wielu przypadkach nieskuteczne preparaty poronne. Jak i inne ówczesne metody, często nie tylko nie spełniały one swojego zadania, lecz również stanowiły poważne zagrożenie dla zdrowia i życia kobiet ${ }^{26}$. W przypadku niepowodzenia $\mathrm{w}$ samodzielnym „przywróceniu miesiączki”, ciężarne szukały pomocy u praktyków, zazwyczaj nieprofesjonalnej, medycyny: znachorów, niewykwalifikowanych akuszerek czy też, najczęściej, tak zwanych „babek”. Rzadziej, i przede wszystkim wśród wyższych warstw społecznych, zwracano się do lekarzy czy felczerów.

Wykształceni specjaliści nauk medycznych odgrywali z kolei dużą rolę w medykalizacji aborcji, która bywała związana zarówno z próbami kryminalizacji przerywania ciąży, jak i liberalizacji prawodawstwa. Na przykład, w USA odejście od wykładni common law nastąpiło stopniowo na poziomie stanowym od lat czterdziestych XIX w. w ramach walki prowadzonej przez Stowarzyszenie Lekarzy Amerykańskich z położnymi i innym niewykwalifikowanym i „nieregularnym” personelem medycznym. Zakaz aborcji stanowił, jak podkreślają badacze, próbę przejęcia kontroli nad kobiecą reprodukcją przez profesjonalnych lekarzy ginekologów, walczących o biomedyczną władzę i finansowe profity z niewykształconymi formalnie akuszerkami ${ }^{27}$. Dążąc do kryminalizacji aborcji, wykwalifikowani lekarze podważali przekonanie o rozpoczynaniu się ciąży od momentu poczucia pierwszych ruchów płodu. Jak podkreśla Leslie Reagan, kwestionowali w ten sposób znaczenie kobiecego doświadczenia cielesnego, usiłując zastąpić subiektywne, niestandardowe i niemierzalne odczucie - wymierną, naukową, medyczną diagnozą ${ }^{28}$.

W Związku Radzieckim, pierwszym państwie, które zalegalizowało przerywanie ciąży z powodów społecznych, władza i decyzje zostały z kolei oddane w ręce lekarzy poprzez zliberalizowanie przedrewolucyjnego prawa. W 1920 r., podobnie jak i od momentu kolejnej zmiany radzieckiego ustawodawstwa w 1955 r.,

\footnotetext{
${ }^{26}$ M. Gawin, op. cit., s. 226; M. Kurkowska, op. cit., s. 157-156. Metody te i środki stosowano również we wcześniejszych epokach, por.: C. Kuklo, Czy społeczeństwo polskie w dobie Oświecenia regulowało liczbę dzieci w rodzinach?, „Roczniki Dziejów Społecznych i Gospodarczych” 51-52, 1990/1991, s. 44-45.

${ }^{27}$ L. Reagan, op. cit., s. 10-11; J.F. Brodie, Contraception and Abortion in 19th-century America, Ithaca and London 1994; J.C. Mohr, Abortion in America. The Origins and Evolution o National Policy, Oxford and New York 1979, s. 34-35.

${ }^{28}$ L. Reagan, op. cit., s. 12.
} 
to lekarze mieli wydawać zezwolenia na przerwanie ciąży, przejmując dzięki temu kontrolę nad praktykami reprodukcyjnymi kobiet ${ }^{29}$. Oddanie decyzji lekarzom i medykalizację aborcji oznaczały również zapisy z polskiego międzywojennego Kodeksu karnego, umożliwiające dokonanie tak zwanej aborcji terapeutycznej w przypadku stwierdzonego przez lekarza zagrożenia dla zdrowia i życia ciężarnej kobiety. Trendy i procesy medykalizacji w dziedzinie kobiecej reprodukcji, w tym aborcji, przybrały zaś w Polsce na sile po II wojnie światowej.

Po 1945 r. jednym z zadań socjalistycznej medycyny, a także pewnym standardem medycznym i zdrowotnym, miało stać się roztoczenie nadzoru lekarza nad praktykami reprodukcyjnymi kobiet, które znajdowały się (wcześniej) w sferze wpływów nieprofesjonalnych i niewykształconych znachorów i „babek”. Korzystanie z usług ludowych, tradycyjnych uzdrowicieli, częste szczególnie na terenach wiejskich, było dla władz przejawem wiejskiej mentalności, ciemnoty i zacofania oraz symbolem starego, przedwojennego ustroju i porządku ${ }^{30}$. Jak podkreśla Barbara Klich-Kluczewska, walka z „babkami” stanowiła zaś jeden z elementów procesu modernizacji wsi prowadzonego w ramach planu 6-letniego ${ }^{31}$.

W oficjalnej państwowej i medycznej retoryce znachorstwo i „babkarstwo” były przyczynami niekorzystnych zjawisk i wskaźników dotyczących zdrowia reprodukcyjnego kobiet oraz zdrowia i życia ich dzieci. Do zjawisk tych należały przede wszystkim: wysoka śmiertelność niemowląt oraz położnic, będąca m.in. skutkiem porodów domowych odbywanych w asyście niewykwalifikowanych „babek”, brak opieki profilaktycznej nad ciążą, nieprawidłowa opieka nad niemowlęciem ${ }^{32}$, a także duża liczba nielegalnych aborcji wywoływanych przez ciężarne kobiety czy też przeprowadzanych przez ich niewykwalifikowane „pomocnice”.

Wysoka śmiertelność niemowląt niepokoiła władze i środowisko lekarskie przez całe pierwsze dziesięciolecie Polski Ludowej. W 1956 r. wynosiła ona w skali kraju 8\%, na niektórych terenach sięgając nawet dwudziestu punktów procentowych. Wskaźnik ten łączono również z brakiem opieki nad ciężarnymi, która szwankowała szczególnie na wsi, gdzie w pierwszej połowie lat pięćdziesiątych

${ }^{29}$ S.G. Solomon, The Demographic Argument in Soviet Debates over the Legalization of Abortion in the 1920s, „Cahiers du monde russe et soviétique” 33, 1992, nr 1, s. 60; A.E. Randall, „Abortion will deprive you of happiness!" Soviet Reproductive Politics in the Post-Stalin Era, „Journal of Women's History" 23, 2011, nr 3, s. 15. Na temat przedrewolucyjnych dyskusji na temat liberalizacji ustawodawstwa dotyczącego aborcji: L. Engelstein, The Keys to Happiness. Sex and the Search for Modernity in Fin-de-Siècle Russia, Ithaca and London 1992, s. 334-358.

${ }^{30}$ E. Szpak, Pojęcie zdrowia, choroby i cielesności w wiejskim postrzeganiu świata po 1945 roku, czyli o zmianach mentalności na wsi polskiej, „Rocznik Antropologii Historii” 2, 2012, nr 1(2), s. 237; W. Piątkowski, op. cit., s. 47.

${ }^{31}$ B. Klich-Kluczewska, Making up for the Losses of War. Reproduction Politics in Post-War Poland, w: Woman and Man at War. A Gender Perspective on World War II and its Aftermath in Central and Eastern Europe, ed. M. Roger, R. Leiserowitz, Osnabruck 2012, s. 319.

32 W. Rostworowska, Tam, gdzie higiena nie dociera, „Służba Zdrowia” 1956, nr 44, s. 5. 
XX w. zaledwie $15 \%$ kobiet znajdowało się pod kontrolą lekarza ${ }^{33}$. Zjawisko to tłumaczono mentalnością, brakiem świadomości i niską kulturą medyczną, sanitarną i seksualną. Kobiety na wsiach, jak możemy się domyślać, nie widziały potrzeby profilaktyki i prewencyjnej opieki nad ciążą, traktując ją jako stan „naturalny”, a nie potencjalnie patologiczny, wymagający nadzoru i opieki. Ponadto, wiejskie społeczności charakteryzowała często niechęć do kontaktów ze środowiskiem lekarskim oraz preferowanie tradycyjnych „uzdrowicieli”: znachorów, nielicencjonowanych akuszerek i „babek”.

Odpowiedzią na opisane powyżej zjawiska stała się próba medykalizacji ciąży, stanowiąca, przynajmniej postulatywnie, jeden z celów społecznej służby zdrowia w Polsce Ludowej. Jej potrzebę artykułowano m.in. w omawianym przeze mnie okresie. Według „wytycznych na przyszłość”, sformułowanych w 1956 r. przez decydentów w Ministerstwie Zdrowia, należało „dążyć [do tego - S.K.-M.] by wszystkie ciąże w możliwie wczesnym okresie były rejestrowane w poradni $\mathrm{K}$, tak by lekarz mógł wpływać rozsądnie na ich los" ${ }^{34}$. Cytowanemu fragmentowi z ministerialnego dokumentu warto przyjrzeć się bliżej, biorąc pod uwagę dwie perspektywy. Pierwsza z nich to rzeczywistość, z którą możemy porównać przytoczone powyżej postulaty. Dotkliwe w omawianym okresie były szczególnie złe warunki lokalowe i infrastrukturalne oraz braki kadrowe, na które skarżyły się na łamach prasy kobiecej ciężarne pacjentki. W 1958 r., czyli dwa lata po wytworzeniu cytowanego dokumentu Ministerstwa Zdrowia, „Przyjaciółka” przytaczała list czytelniczki, narzekającej, że została odesłana bez kontroli z poradni: „powiedziano mi, że czwarty miesiąc, to jeszcze dla nich nie ciąża, że przyjmują tylko wtedy, gdy ciężarna odczuwa już ruchy"35. W wypowiedzi tej widoczny jest jeden istotny element: postrzeganie ciąży jako zaczynającej się dopiero $\mathrm{w}$ momencie poczucia ruchów płodu, wcześniej zaś uważanej za zakrzepłą krew miesiączkową. Możemy stąd wnioskować, że w drugiej połowie lat pięćdziesiątych XX w. tradycyjny i przednowoczesny pogląd na temat początków ciąży utrzymywał się nie tylko wśród kobiet, lecz również (zapewne niekiedy) w obrębie środowiska medycznego.

Druga perspektywa to wyartykułowany w dokumencie Ministerstwa Zdrowia postulat objęcia ciąży opieką lekarską od jej najwcześniejszego etapu. Zastanawiający jest w tym miejscu zwłaszcza fragment o „rozsądnym wpływie lekarza na jej [ciąży - S.K.-M.] los”, który skłania do postawienia pytań o możliwość potencjalnego zakończenia „stanu odmiennego", będącego skutkiem decyzji podjętej nie przez kobietę, lecz przez ginekologa. Czy na sformułowanie zapisu w rekomendacjach miał wpływ okres ich tworzenia: moment zmian w ustawie

${ }^{33}$ AAN, MZ, sygn. 1/27, Stan opieki położniczej i ginekologicznej w kraju i wytyczne na przyszłość, 1956 r., k. 229.

${ }^{34}$ Ibidem, k. 231.

${ }^{35}$ Po prostu kpiny, „Przyjaciółka” 1958, nr 23, s. 7. 
o warunkach przerywania ciąży? Czy dlatego w dokumencie pojawiło się sformułowanie o „możliwie wczesnym okresie [ciąży - S.K.-M.]”, kiedy to według nowego ustawodawstwa można było podjąć decyzję o aborcji? Warto w tym aspekcie zwrócić również uwagę na przymiotnik „rozsądny”; użyty do opisania działania lekarza wskazywał on na profesjonalistę jako na osobę predysponowaną do podejmowania decyzji o utrzymaniu lub zakończeniu ciąży.

O ile w przypadku ciąży problem z punktu widzenia przedstawicieli socjalistycznej służby zdrowia stanowił przede wszystkim brak opieki, to w momencie jej rozwiązania, czyli porodu, sytuacja stawała się jeszcze bardziej nienormatywna ze względu na wkroczenie nowego „aktora”: tak zwanych babek. „Babki” - zazwyczaj starsze, doświadczone, często wielodzietne kobiety, głównie z wiejskich społeczności, stanowiły pozostałość tradycyjnych praktyk leczniczych, nadal obecną po II wojnie światowej. W latach pięćdziesiątych XX w. miały one wciąż duży wpływ na praktyki reprodukcyjne kobiet, szczególnie na wsiach, przyjmując domowe porody ${ }^{36}$ oraz, o co oskarżały je medyczne elity, przeprowadzając dużą liczbę kryminalnych aborcji.

Pomimo obowiązującego w Polsce po II wojnie światowej zakazu przerywania ciąży poza przypadkami jej pochodzenia z przestępstwa oraz zagrożenia dla życia matki, co roku kilkaset tysięcy kobiet samotnie czy też przy pomocy innych osób, często tradycyjnych akuszerek ${ }^{37}$, dokonywało nielegalnych sztucznych poronień. Liczbę wykroczeń tego rodzaju zwiększyło prawdopodobnie zaostrzenie przepisów w 1948 r., skutkujące powołaniem komisji przyszpitalnych, mających wydawać zgodę na przerwanie ciąży z przyczyn medycznych ${ }^{38}$. W 1956 r., w momencie zmiany ustawy, szacowano, że w Polsce rocznie ma miejsce ok. 300 tys. kryminalnych aborcji, zaś ok. 80 tys. kobiet trafia z rozpoczętym poronieniem do szpitala ${ }^{39}$. Trzy lata wcześniej podejrzewano, że $2 / 3$ z ok. 80 tys. poronień rozpoczętych poza szpitalem stanowiły nielegalne interrupcje ${ }^{40}$. Liczba ta w rzeczywistości oznaczała liczbę komplikacji po „domowych” aborcjach wywołanych przez same ciężarne bądź też nieprofesjonalne akuszerki. Ich skutkiem często był znaczny uszczerbek na zdrowiu czy nawet śmierć kobiety chcącej pozbyć się niepożądanej ciąży.

W publikacjach powstających w kręgach Towarzystwa Świadomego Macierzyństwa, w broszurach dotowanych przez Ministerstwo Zdrowia, w katolickiej

\footnotetext{
${ }^{36}$ W. Kasprzak, W klinice - czy w domu?, „Służba Zdrowia” 1955, nr 17, s. 3.

${ }^{37}$ Por. np.: B. Klich-Kluczewska, Przypadek Marii spod Bochni. Próba analizy mikrohistorycznej procesu o aborcję z 1949 r., „Rocznik Antropologii Historii” 2, 2012, nr 1(2), s. 195-209.

${ }^{38}$ A. Titkow, Poland, w: From Abortion to Contraception. A Resource to Public Policies and Reproductive Behavior in Central and Eastern Europe from 1917 to the Present, ed. H.P. David, Westport, Connecticut 1999, s. 172.

${ }^{39}$ K.L., Lekarz głównym wykonawca ustawy o warunkach dopuszczalności przerywania ciąży, "Służba Zdrowia” 1956, nr 21, s. 4.

${ }^{40}$ AAN, MZ, sygn. 1/27, Stan opieki położniczej..., k. 227.
} 
publicystyce: wszędzie „babki” figurowały jako niewykwalifikowane i niebezpieczne praktykantki zabobonu i nieprofesjonalnej medycyny. Rzadko, jak w historii Łukaszki zawartej na stronach anty-„,babkowego” zbioru opowieści Sprawy życia, sprawy śmierci autorstwa Macieja Kwiatkowskiego, przedstawiano je jako osoby przejęte losem kobiet przychodzących po pomoc w przerwaniu niechcianej ciąży. Do opisu ludowych akuszerek używano takich określeń jak „cyniczna”, „brutalna”, z grymasem obojętności na twarzy ${ }^{41}$. Nawet opowiadanie zatytułowane Dobre serce Łukaszki poddaje w wątpliwość motywy działania „babek”, wskazując na skutki „popsucia ciąży” kończącego się śmiercią dziewczyny, szukającej pomocy u ludowej akuszerki. Opisując reakcję Łukaszki na widok karetki zabierającej zakrwawioną Jadźkę, narrator opowiadania podkreśla: „trwożnie nakreśliła znak krzyża na wyschłej piersi tą samą ręką, która wczoraj trzymała krzywy ostry drut" ${ }^{\prime 2}$. Dłonie Łukaszki i zadana przez nie, mimo że nieintencjonalnie, śmierć, stają się głównym motywem w narracji obecnej na stronach kilkukrotnie wznawianej wysokonakładowej książeczki wydanej w popularnej serii „Zdrowie dla wszystkich” Państwowego Zakładu Wydawnictw Lekarskich. Jak z pełną mocą stwierdza na końcu opowiadania jego autor: „najwyższy czas, porazić te ręce, niosące śmierć i kalectwo"43.

W opisach działalności aborcyjnej „babek”, obecnych na kartach różnego typu źródeł, można wyróżnić kilka wyraźnych motywów. Po pierwsze, ludowe akuszerki miały stosować metody przerywania ciąży wyjątkowo mocno zagrażające życiu i zdrowiu kobiet. $Z$ jednej strony były to środki mechaniczne, które, jak w przypadku Jadźki, mogły zadać kobiecemu organizmowi „straszny gwałt", przebijając kilkakrotnie ściany macicy ${ }^{44}$. W opisach metod przerywania ciąży wykorzystywanych przez „babki” powszechnie podkreślano ich „barbarzyństwo". Kończąc opisywać historie skrzywdzonych przez kryminalne aborcje kobiet, autor Spraw życia, spraw śmierci stwierdzał: „po wsiach i miastach «babki» uprawiają swój proceder posługując się arsenałem środków, przy którym blednie średniowieczna izba tortur” 45 . "Straszniejsi” od wiejskich „przerywaczek” byli, według jednej z lekarek, tylko „kowale lub inni majstrowie”, używający np. „gwoździa nabitego na patyk, albo żelaznego pręta czy po prostu zaostrzonego kawałka drewna"46.

\footnotetext{
${ }^{41}$ M. Kwiatkowski, Sprawy życia i sprawy śmierci, Warszawa 1956, s. 30-31, 48.

${ }^{42}$ Ibidem, s. 19.

${ }^{43}$ Ibidem, s. 20.

${ }^{44}$ Ibidem, s. 19. Na temat stosowania przez „babki” środków mechanicznych por. np.: W. Gabler, Z. Janczewski, O przerywaniu ciąży, Warszawa 1957, s. 43; R. Pumpiański, Higiena $w \dot{z} y c i u$ kobiety, Warszawa 1956, s. 57; idem, Jak zapobiegać ciąży, Warszawa 1957, s. 22; Zdrowie kobiety, red. J. Lesiński, R. Pumpiański, Warszawa 1957, s. 62.

${ }^{45}$ M. Kwiatkowski, op. cit., s. 73.

${ }^{46}$ J. Beaupré, Jak zapobiegać ciąży, Warszawa 1959, s. 23-24.
} 
Drugim zazwyczaj stosowanym przez „babki” sposobem przerywania ciąży było według lekarzy i publicystów wstrzykiwane do macicy roztworów spirytusu, jodyny czy mydła ${ }^{47}$. Używana do tego zabiegu gumowa rurka stała się motywem przewodnim innej historii zawartej w Sprawach życia, sprawach śmierci. Pojawia się w opowiadaniu o Mariannie Stareckiej, sądzonej za złamanie artykułu 230 Kodeksu karnego. Starecka: „starsza, otyła kobieta, z grymasem na twarzy” zostaje skazana na sześć lat pozbawienia wolności za dokonanie dwóch nielegalnych aborcji, które kończą się śmiercią kobiet szukających u niej pomocy ${ }^{48}$. Woda mydlana i inne płyny używane do przerwania ciąży były uważane za szczególnie niebezpieczne dla zdrowia kobiet. Autorzy popularnych broszur wymieniali możliwe konsekwencje ich użycia: „ciężkie schorzenia macicy i jajowodów”, niepłodność, ciąże pozamaciczne czy poronienia nawykowe ${ }^{49}$. Jadwiga Beaupré związana z krakowskim oddziałem Towarzystwa Świadomego Macierzyństwa pisała w Jak zapobiegać ciąży: „,roztwór mydła [...] może wywołać śmierć pacjentki powodując, gdy się dostanie do krwiobiegu, ciężkie, nieodwracalne zatrucie całego organizmu" 50 .

W pracach i dokumentach opisujących metody przerywania ciąży stosowane przez „babki” zwracają uwagę również zabiegi retoryczne i narracyjne mające na celu uwypuklenie różnicy pomiędzy profesjonalną i ludową/nienaukową medycyną. W retoryce socjalistycznych lekarzy i decydentów „babki” uosabiały dyletancką praktykę medyczną, opierającą się na zabobonie oraz ustnej tradycji, umiejętnościach praktycznych i doświadczeniu. Jak pokazują prace badaczy nauk społecznych, cechy te charakteryzowały medycynę ludową, której praktycy byli zazwyczaj blisko i silnie związani z leczonymi przez nich społecznościami. W ramach medycyny ludowej, kwestiami związanymi z reprodukcją, zwłaszcza żeńskiej części danej wspólnoty, zajmowały się przede wszystkim kobiety posiadające doświadczenie i umiejętności praktyczne z dziedziny antykoncepcji, ciąży, porodu, połogu, a także „spędzania płodu” ${ }^{2}$. W krajach i społeczeństwach nowoczesnych, do miana których z kolei pretendowały władze Polski Ludowej, uznawano prymat medycyny profesjonalnej: naukowej, empirycznej, stechnicyzowanej, autokratycznej i zbiurokratyzowanej ${ }^{52}$. Wiedza naukowa, zgodnie z teoriami Michaela Foucault, stawała się w tym kontekście prerogatywą i podwaliną

\footnotetext{
${ }^{47}$ T. Bulski, Poradnik małżeński, Warszawa 1962, s. 38; J. Beaupré, op. cit., s. 23.

${ }^{48}$ M. Kwiatkowski, op. cit., s. 48 n.

${ }^{49}$ Por. np.: R. Pumpiański, Higiena w życiu..., s. 57; idem, Jak zapobiegać..., s. 22; Zdrowie kobiety..., s. 62.

${ }^{50}$ J. Beaupré, op. cit., s. 23.

${ }^{51}$ W. Piątkowski, op. cit., s. 20, 37, 79-81, 85. Na temat roli „babek” por. także: Z. Libera, Znachor $w$ tradycjach ludowych i popularnych XIX-XX w., Wrocław 2003, s. 67, 131, 213-215; I. Jaguś, Lecznictwo ludowe w Królestwie Polskim na przełomie XIX i XX w., Kielce 2002, s. 57-58.

${ }^{52}$ W. Piątkowski, op. cit., s. 11.
} 
hierarchii i władzy; zaś praktykami reprodukcyjnymi kobiet zarządzali zazwyczaj lekarze mężczyźni.

Odwołując się do podziału na naukową i ludową medycynę, publicyści i lekarze ukazywali nieprofesjonalne praktyki „babek” jako oparte w dużym stopniu na zabobonie. W jednej z historii opisanej w Sprawach życia, sprawach śmierci wykonująca aborcję „babka” figuruje jako przedstawicielka „ciemnych przedpotopowych sił" ${ }^{33}$. Przesądy i ludową medycynę w najczystszej postaci uosabiała opisywana już Łukaszka, która nie tylko dała Jadźce do wypicia kubek mocno pachnących ziół, lecz również „mamrotała coś pod nosem i kiwała się czyniąc dziwne znaki”, aby później obchodzić dziewczynę z szufelką węgli z paleniska, na które uprzednio została rzucona garść zió ${ }^{54}$. W historii Łukaszki i Jadźki symptomatyczne jest również praktyczne zrównanie zabobonu i religii. „Babka” nie tylko „nakreśla znak krzyża”, lecz również chodzi wokół łóżka, „szepcząc zaklęcia czy też modląc się"55.

Ponadto, praktyki „babek” ukazywano jako czynności wykonywane przez dyletantki niezgodnie z najnowszymi standardami medycznymi i naukowymi. Niewykwalifikowane akuszerki określano jako „pokątne”, „niepowołane” czy „domorosłe”, z „niewprawną ręką", a przy opisie ich działań często pojawiały się słowa: niesanitarne, antysanitarne i niehigieniczne ${ }^{56}$. Z nieprofesjonalnymi "babkami” zostali zaś skontrastowani lekarze specjaliści, będący w posiadaniu naukowej, medycznej wiedzy. Jadwiga Beaupré pisała w wysokonakładowej broszurze: „jeżeli przerywanie ciąży jest konieczne, niech je wykona dobry, doświadczony ginekolog i najlepiej w szpitalu" ${ }^{27}$. Konieczność posiadania dużej wiedzy medycznej, niezbędnej do przeprowadzenia zabiegu aborcji, podkreślali również Wiktor Gabler i Zygmunt Janczewski, wymieniając w swej książce specjalistów uprawnionych do przerywania ciąży: ginekologów, położników i chirurgów ${ }^{58}$. W retoryce tej, interrupcje zostały ukazane jako skomplikowane zabiegi medyczne, wymagające specjalistycznego przygotowania i naukowej wiedzy. Nawet jednak jej posiadanie nie gwarantowało, jak pokazuje wiele publikacji, braku komplikacji i zdrowotnych konsekwencji. Cytowani powyżej autorzy, ukazując zabieg przerywania ciąży jako potencjalnie szkodliwy i niebezpieczny, autorytatywnie stwierdzali: „przebicie macicy jest często niezależne od umiejętności i wprawy lekarza" ${ }^{59}$, poddając w ten

\footnotetext{
${ }^{53}$ M. Kwiatkowski, op. cit., s. 39.

${ }^{54}$ Ibidem, s. 18.

${ }^{55}$ Ibidem.

${ }^{56}$ R. Pumpiański, Jak zapobiegać..., s. 22-23; W. Gabler, Z. Janczewski, op. cit., s. 43; J. Beaupré, op. cit., s. 23; T. Bulski, op. cit., s. 38; J. Lesiński, Zarys zapobiegania ciąży. Dla lekarzy i studentów medycyny, Warszawa 1961, s. 17.

${ }^{57}$ J. Beaupré, op. cit., s. 26-27.

${ }^{58}$ W. Gabler, Z. Janczewski, op. cit., s. 49.

${ }^{59}$ Ibidem, s. 44-45.
} 
sposób w wątpliwość forsowane przez specjalistów twierdzenie o skuteczności profesjonalnej medycyny.

Komplikacje, w tym zgony i poważne konsekwencje dla zdrowia kobiet pojawiały się z kolei zawsze i nieodzownie w przypadku aborcji wykonanych przez „babki”. Publikacje lekarzy i publicystów wypełnione są historiami przerywających ciąże kobiet, dla których ratunku szuka się wśród przedstawicieli profesjonalnej medycyny. Karetki pogotowia, jak w historii Jadźki i Łukaszki, zabierają kobiety do szpitala, gdzie jednak „barbarzyństwo” popełnione przez „babkę” często jest zbyt wielkie, by mógł mu zaradzić nawet specjalista. Jadźka umiera po zadaniu jej „ciosu śmiertelnego, wobec którego wiedza medyczna stała się bezsilna” 60 . Bezradność lekarza opisana w książce Kwiatkowskiego nie ma na celu podważenia wiedzy i umiejętności medyka; jest ona jednoznacznie manifestacją zbrodniczej potencjalności zabiegów wykonywanych przez nieprofesjonalistki.

Kontrast pomiędzy naukową medycyną i ludowymi czy też nienadzorowanymi przez lekarza praktykami widać nie tylko w przypadku tych najcięższych, śmiertelnych konsekwencji. W lekarskich i popularnych publikacjach pomocy u specjalistów szukają również pacjentki, u których „pokątne" zabiegi przerywania ciąży spowodowały choroby, przede wszystkim bezpłodność. Zajść w ciążę nie są w stanie nie tylko kobiety korzystające wcześniej z usług „partaczek”, lecz również te na własną rękę i za namową koleżanek korzystające z zastrzyków i proszków mających spowodować sztuczne poronienie. Pojawiające się często w publikacjach z lat pięćdziesiątych i wczesnych lat sześćdziesiątych XX w. „zastrzyki na ciążę" świadczyć mogą o dużej popularności tej metody „przywracania miesiączki” $\mathrm{w}$ analizowanym okresie ${ }^{61}$. Wstrzykiwanie syntofoliny i folikuliny - jak podkreślali publicyści i lekarze - nie miało efektu aborcyjnego, a prowadziło do zaburzeń równowagi hormonalnej $\mathrm{w}$ organizmie $\mathrm{i}, \mathrm{w}$ częstych przypadkach, do bezpłodności. W przypadku „zastrzyków na ciążę” jako nieprofesjonalne doradczynie medyczne występowały jednak nie „babki”, a zazwyczaj znajome i koleżanki. Były one mniej retorycznie demonizowane; ich porady mogły jednak również doprowadzić do medycznego nieszczęścia, pomocy w którym kobiety szukać miały u specjalistów posiadających naukową wiedzę medyczną.

Wszystkie powyżej opisywane nieprawidłowości, wywodzące się z praktykowania aborcji przez dyletanckie przedstawicielki nieprofesjonalnej medycyny: „babki” i w mniejszym stopniu koleżanki i znajome, miała zniwelować ustawa z 1956 r. Na łamach branżowej „Służby Zdrowia” przestawiano nowe prawodawstwo jako krok w stronę przejęcia kontroli nad aborcją z rąk nielegalnych akuszerek i „złączonych z nimi wspólnym przestępstwem” kobiet ${ }^{62}$. W artykule

\footnotetext{
${ }^{60}$ M. Kwiatkowski, op. cit., s. 19.

${ }^{61}$ Ibidem, s. 25; T. Bulski, op. cit.; Zdrowie kobiety..., s. 59.

${ }^{62}$ K.L., Lekarz głównym wykonawcą ustawy..., s. 4.
} 
omawiającym nowe rozporządzenie, zdesperowane ciężarne przedstawiono jako ofiary, „babkom” zaś przydano rolę oprawców. Pozostawiona sama sobie kobieta „trafiała w ręce «babek», których pomysłowość w tym zakresie była zastraszająca. Pomimo tragicznych skutków metod stosowanych przez «babki» jednak nie dosięgała ich sprawiedliwość. Kobieta złączona $\mathrm{z}$ «babką» wspólnym przestępstwem milczała pomimo wszystko"63.

Pisząc o istnieniu przed 1956 r. „pewnego rodzaju podziemia”, w którym nielegalnego przerywania ciąży dokonywały „niewykfalifikowane położne, różne «babki» a nawet kowale”64, redaktorzy „Służby Zdrowia” dokonywali retorycznej próby rozbicia kobiecej solidarności i współwiny, które naznaczały relację pomiędzy dokonującą sztucznego poronienia "babką" i poddającą się aborcji kobietą. Ten sam cel, podkreślany w jednym z artykułów w „Służbie Zdrowia”, stawiała przed sobą nowa ustawa. Nie przewidując kary dla kobiety dokonującej przerwania ciąży, "rozrywała” nić pomiędzy dwiema uprzednimi przestępczyniami. Poddająca się aborcji kobieta dzięki ustawie przestawała w tej narracji być sprzymierzeńcem „babki”, złączonym z nią wspólnym przestępstwem.

„Wypowiadając wojnę wszelkim babkom”65, ustawa miała jednocześnie, według redaktorów branżowego czasopisma, postawić przez kobietą innego „sprzymierzeńca": lekarza, stającego się osobą nadzorującą praktyki reprodukcyjne żeńskiej części społeczeństwa, mającego chronić ciężarne przed niewykwalifikowanymi położnymi ${ }^{66}$. W nowej retoryce, nielegalne sztuczne poronienia sprzed $1956 \mathrm{r}$. oznaczały nie tylko łamanie prawa, lecz również narażanie zdrowia kobiet i ich przyszłych zdolności reprodukcyjnych na wielkie niebezpieczeństwo. Oficjalnie, legalna aborcja miała umożliwić kobietom wykonywanie zabiegu w bezpieczniejszych dla ich zdrowia warunkach, zapewnionych dzięki obecności i nadzorowi wykwalifikowanego lekarza. Ustawa z 1956 r. i następująca po niej kampania na rzecz świadomego macierzyństwa stanowiły w tej retoryce element podniesienia stanu zdrowotności kobiet, których życiu i kondycji zagrażały przesądy i nienaukowe praktyki medyczne uosabiane przez niewykształcone „babki”.

Jednocześnie warto zaznaczyć, że z oficjalną linią scharakteryzowanej powyżej argumentacji nie zgadzali się publicyści i przedstawiciele środowiska medycznego związani z Kościołem katolickim. W dyskusjach na łamach prasy podkreślali, że dopuszczenie do wykonywania legalnej aborcji przez lekarza czyni z przerywania ciąży taki sam zabieg jak każdy inny, bez wzięcia pod uwagę jego konsekwencji ontologicznych. Według jednego z reprezentantów tego środowiska, Antoniego B. Henkego: „dla uświadamiania społeczeństwu zła ze sztucznych poronień jest całkiem co innego, gdy przerywają ciąże położne i «babki», a zupełnie co innego,

\footnotetext{
${ }^{63}$ Ibidem.

${ }^{64}$ L. Krotkiewska, Gdzie tu gwałcenie wolności sumienia, „Służba Zdrowia” 1957, nr 16, s. 2.

${ }^{65}$ Ibidem.

${ }^{66}$ Ibidem.
} 
gdy dopuszczają się tego lekarze legalnie"67. Dekryminalizacja aborcji, jak zdaje się argumentować Henke, stawiała przedstawicieli naukowej, profesjonalnej medycyny na tym samym poziomie co pokątne „partaczki” i praktykantki zabobonu, zaś zezwolenie na wykonywanie zabiegów przez lekarzy legitymizowało przerywanie ciąży.

Ustawa z 1956 r. umożliwiała legalne przerwanie ciąży w przypadku przestępstwa, zagrożenia dla zdrowia i trudnej sytuacji życiowej kobiety. Wprowadzała jednocześnie znaczne obostrzenia $\mathrm{w}$ dostępie do aborcji, $\mathrm{z}$ których wiele miało charakter natury medycznej ${ }^{68}$. Skierowanie na przerwanie ciąży wystawiał lekarz, który nie mógł jednak sam wykonać zabiegu. Lekarz również wydawał zgodę na przeprowadzenie sztucznego poronienia w przypadku wskazań społecznych, opierając się na zaświadczeniach np. z komitetu blokowego czy od pielęgniarki patronażowej potwierdzających trudną sytuację życiową kobiety. Podsumowując, ustawa z 1956 r. przenosiła punkt uwagi i decyzyjność na lekarza, dokonując tym samym bardzo istotnego zabiegu medykalizacji przerywania ciąży ${ }^{69}$.

Jednocześnie, konstruowanie aborcji jako problemu medycznego odbywało się po 1956 r. nie tylko poprzez oddanie decyzji o jej przeprowadzeniu w ręce środowiska lekarskiego. Drugim wymiarem tego procesu stało się definiowanie i przedstawianie sztucznych poronień jako choroby. Zabieg ten wzmacniał argument o konieczności kontroli przerywania ciąży przez specjalistę, ukazując je jako patologię kobiecego życia reprodukcyjnego.

Nazywając aborcję chorobą, zarówno związani z władzami lekarze i publicyści, jak i medycy wyrażający swe opinie na łamach prasy katolickiej odwoływali się często do wypowiedzi nestora polskiej ginekologii, Adama Czyżewicza. Dążąc do ograniczenia liczby interrupcji w przypadku pierwszej z wymienionych grup i opowiadając się za całkowitą kryminalizacją sztucznych poronień w przypadku drugiej, uczestnicy debaty powoływali się na opinię wyartykułowaną przez wybitnego ginekologa w 1927 r. Podkreślając, że zdanie Czyżewicza zachowało swoją wartość pomimo postępów w medycynie, Gabler i Janczewski cytowali słowa profesora: „każde poronienie, samoistne czy sztuczne, jest zawsze chorobą, która nierzadko może mieć poważne następstwa daleko sięgające, nie dające się obliczyć"70. Do tej samej wypowiedzi odwoływali się lekarze publikujący na łamach

${ }^{67}$ A.B. Henke, W sprawie stanowiska poprawnego medycznie lekarza wobec problemu niszczenia ciąży, „Ateneum Kapłańskie” 55, 1957, z. 2(292), s. 244.

${ }^{68} \mathrm{Na}$ temat ustawy i dyskusji sejmowej wokół niej: A. Czajkowska, O dopuszczalności przerywania ciąży. Ustawa $z$ dnia 27 kwietnia 1956 r. i towarzyszące jej dyskusje, w: Kłopoty z seksem w PRL. Rodzenie nie całkiem po ludzku, aborcja, choroby, odmienności, red. M. Kula, Warszawa 2012, s. 99-186.

${ }^{69} \mathrm{Na}$ temat podobnego zabiegu i procesu w Finlandii, por.: M. Meskus, To Exclude or To Enclose: Medicalization of Abortion in Finland, 1900-1950, „Scandinavian Journal of History” 30, 2005, nr 1, s. 45-60.

${ }^{70}$ W. Gabler, Z. Janczewski, op. cit., s. 56. 
„Ateneum Kapłańskiego”, a słowa Czyżewicza przedrukowywała w analizowanym przeze mnie okresie prasa katolicka, m.in. „Słowo Powszechne”

Uznając naturalny poród za stan zdrowia i definiując samoistne i sztuczne poronienia jako chorobę, publicyści i lekarze z różnych opcji ideowych kierowali jednobrzmiące, zmedykalizowane przesłanie do wszystkich kobiet. Zgodnie z nim aborcja jako „poważna operacja” miała być szkodliwa dla kobiecego zdrowia we wszystkich przypadkach, łącząc się z ryzykiem zarówno dla dobrostanu fizycznego, jak i psychicznego ${ }^{72}$. Sztuczne poronienie, według Kwiatkowskiego, nigdy nie miało mijać bez śladu ${ }^{73}$. Ryzyko nieść miał ze sobą każdy zabieg, nawet ten wykonywany przez „najbardziej doświadczonego specjalistę"74. Według katolickich lekarzy, powikłania zdarzały się nawet po aborcjach przeprowadzanych w szpitalach, o czym kobiety powinny być informowane ${ }^{75}$. Z tego też względu - zgadzali się związani z władzami lekarze - sztucznego poronienia powinno się dokonywać tylko w ostateczności ${ }^{76}$.

Chorobotwórczy aspekt przerywania ciąży był podkreślany przez medyków nie tylko w aspekcie konsekwencji aborcji dla zdrowia kobiety, lecz również dla dobrostanu całego społeczeństwa. Wybitny polski ginekolog, Jan Lesiński, pisał w podręczniku dla lekarzy i studentów medycyny, że poronienie jest „zjawiskiem bardzo groźnym dla zdrowia publicznego"77, wskazując na negatywny wpływ przerywania ciąży dla kondycji populacji. Lesiński podkreślał, że nie ma w tym przypadku na myśli potencjału demograficznego narodu polskiego wyrażanego przez zdolności reprodukcyjne żeńskiej części społeczeństwa. Zdrowie publiczne zdawał się rozumieć bardziej jako dobrostan fizyczny i psychiczny kobiet niecierpiących na różnorakiego typu zaburzenia.

W argumentacji prezentowanej przez środowisko medyczne po uchwaleniu ustawy o warunkach przerywania ciąży nie sposób nie zauważyć paradoksalnej sprzeczności z omawianą wcześniej, „anty-babkarską" retoryką. Przedstawiając pokątne sztuczne poronienia jako niebezpieczeństwo dla życia i zdrowia kobiet, ustawodawcy oficjalnie dążyli do zapobieżenia temu zagrożeniu poprzez liberalizację prawa dopuszczającego przerywanie ciąży w wybranych przypadkach. Jednocześnie jednak, na łamach branżowych pism, popularnych wydawnictw zdrowotnych czy katolickiej prasy wytwarzany był inny, patologizujący dyskurs,

${ }^{71}$ Stanowisko lekarza katolika..., s. 241.

72 W. Gabler, Z. Janczewski, op. cit., s. 42; Zdrowie kobiety..., s. 63-64. Na temat mechanizmu formułowania się argumentu o szkodliwości aborcji dla zdrowia psychicznego kobiet, por. E. Lee, Abortion, Motherhood, and Mental Health. Medicalizing Reproduction in the United States and Great Britain, New York 2003.

${ }^{73}$ M. Kwiatkowski, op. cit., s. 68-69.

${ }^{74}$ J. Pumpiański, Higiena $w \dot{z ̇ y c i u . . ., ~ s . ~} 57$.

${ }^{75}$ B. i J. Matyjkowie, op. cit., s. 284.

${ }^{76}$ Życie wyprzedza ustawę, „Służba Zdrowia” 1956, nr 17, s. 6.

77 J. Lesiński, op. cit., s. 17. 
przedstawiający sztuczne poronienia jako chorobę. Nie odwoływano się w nim, jak w „anty-babkarskiej” literaturze, do przypadków śmierci poddających się interrupcji kobiet. Ukazywano jednak sztuczne poronienie jako zawsze i nieodwołalnie prowadzące do poważnych, negatywnych konsekwencji zdrowotnych. Jak pokazują Agata Ignaciuk i Amy E. Randall, argumentacja ta cechowała socjalistyczną antyaborcyjną retorykę obecną w Polsce Ludowej i w Związku Radzieckim również przez kolejne dekady ${ }^{78}$.

Przy przedstawianiu drugiego poziomu medykalizacji przerywania ciąży warto uwzględnić jeszcze jedną perspektywę, przyglądając się uważnie argumentom o zdrowiu kobiet używanym w dyskusji toczącej się w drugiej połowie lat pięćdziesiątych XX w. na łamach prasy branżowej. W debacie tej znika spójny przekaz o aborcji jako chorobie, wysyłany do opinii publicznej przez odmienne frakcje środowiska lekarskiego; pojawiają się z kolei różnice artykułowane przez różne grupy medycznych specjalistów oraz wątki ekonomiczne i klasowe.

Wymiana zdań na temat ustawy z 1956 r. i roli lekarzy w jej realizacji toczyła się m.in. na łamach „Służby Zdrowia”. Zapoczątkował ją „List otwarty do kolegów ginekologów" opublikowany na łamach tygodnika jesienią $1956 \mathrm{r} .{ }^{79}$ Kilka miesięcy po wprowadzeniu ustawy jego autorzy apelowali do ginekologów o niepodejmowanie sabotujących kroków uniemożliwiających kobietom wykonanie zabiegu przerywania ciąży pomimo spełniania wymaganych wskazań zdrowotnych i społecznych. Problem ten był w kolejnych latach wielokrotnie poruszany na różnych łamach, także czasopism kobiecych. W artykułach prasowych opisywano spory ideowe oraz zwracano uwage na braki infrastrukturalne i problemy logistyczne utrudniające kobietom dostęp do legalnych sztucznych poronień ${ }^{80}$.

W dyskusji na stronach „Służby Zdrowia” argumentu o pewnej i niekwestionowanej szkodliwości aborcji dla zdrowia kobiet używała grupa podpisująca się jako „ginekolodzy warszawscy”. Byli to lekarze związani z Kościołem katolickim; część z nich, jak Jolanta Massalska czy Emilia Paderewska-Chrościcka, zaangażowała się w kolejnych dekadach w tworzenie w Polsce ruchu antyaborcyjnego oraz zakładanie przykościelnych poradni propagujących naturalne metody planowania rodziny ${ }^{81}$.

${ }^{78}$ A. Ignaciuk, „Ten szkodliwy zabieg”. Dyskursy na temat aborcji w publikacjach Towarzystwa Świadomego Macierzyństwa / Towarzystwa Planowania Rodziny (1956-1980), „Zeszyty Etnologii Wrocławskiej" 20, 2014, nr 1, s. 90-96; A.E. Randall, op. cit., passim.

${ }^{79}$ List otwarty do kolegów ginekologów, „Służba Zdrowia” nr 42, 1956, s. 1.

${ }^{80}$ Dziwny warunek, „Przyjaciółka” 1961, nr 19, s. 7 i 10; M. Cześninowa, Ustawa nie zlikwidowała szkodliwych zjawisk, „Służba Zdrowia” 1956, nr 46, s. 3; E. Dorengowski, Pacjentki czekaja, „Służba Zdrowia” 1956, nr 44, s. 5; S. Kalicki, Dlaczego kobieta wybiera „podziemie” gdy decyduje się na przerwanie ciąży?, „Służba Zdrowia” 1958, nr 10, s. 4.

${ }^{81}$ Por. np.: J. Massalska, Natura ludzka - norma seksualna - planowanie rodziny, „Więż" 1962, nr 8, s. 85-91; eadem, Lekarze wobec życia nienarodzonego - rozmowa $z$ dr. med. J. Massalska, „Z Pomocą Rodzinie” 1981, nr 3, s. 137-145; na temat Emilii Paderewskiej-Chrościckiej: A. Chrościcki, Matka tysiąca dzieci. Wspomnienia o Emilii Paderewskiej-Chrościckiej, Warszawa 2001. 
Po 1956 r. odmawiali oni przeprowadzania sztucznych poronień, wyjaśniając, że ich reakcja na nowe prawodawstwo jest „oporem lekarza, który nie chce szkodzić i człowieka, który nie chce zabijać" 82 . W kontekście mojej analizy szczególnie ważna jest pierwsza część tej wypowiedzi. Pokazuje ona pogląd artykułowany przez środowisko ginekologów katolickich wskazujących na szkodliwość wszystkich, nawet legalnych aborcji. Podkreślając konsekwencje zdrowotne sztucznych poronień, katoliccy ginekolodzy jednocześnie konstruowali swoją zawodową tożsamość jako grupa specjalistów najlepiej znających się na zdrowiu reprodukcyjnym kobiet. Nie bez przyczyny używając zaimka osobowego w pierwszej osobie liczby mnogiej, pisali: „M y g i n e k olo d z y [wyróżnienie - S.K.-M.] [...] leczymy wielki uraz, zadany zdrowiu kobiety przez zabieg przerywania ciąży. My leczymy powikłania, jakie po nim powstają - choćby nawet był wykonany najbardziej fachowo w warunkach szpitalnych. My oglądamy zaburzenia układu wewnątrzwydzielniczego i nerwowego, które sprowadza przerwanie ciąży - a sprowadza je z reguły [wyróżnienie oryg.], choćby nawet nie było żadnych powikłań miejscowych bezpośrednio po zabiegu" 83 .

Odmawiając wykonywania zabiegu przerywania ciąży, ginekolodzy warszawscy odnosili się do własnej eksperckiej wiedzy i doświadczenia, ukazując aborcję jako problem przede wszystkim medyczny ${ }^{84}$. Pozwalało to im na użycie bardziej „profesjonalnego" dyskursu niż odwołania do statusu ontologicznego zarodka i płodu. Poza tym stanowiło poręczną broń w dyskusji z drugą stroną, którą w wymianie zdań na łamach „Służby Zdrowia” stanowili lekarze z innych profesji. „List otwarty do kolegów ginekologów” na łamach branżowego czasopisma opublikowali bowiem interniści, pediatrzy i specjaliści od chorób płucnych ${ }^{85}$. Głównym oponentem ginekologów warszawskich był Tadeusz Kielanowski, twórca oddziału lekarskiego na UMCS i pierwszy rektor Akademii Medycznej w Białymstoku ${ }^{86}$. Kielanowski i pozostali sygnatariusze wysłanego z Białegostoku listu patrzyli na sztuczne poronienia z odmiennej perspektywy. Pneumolodzy (na przykład podpisany pod listem Stanisław Gajewski ${ }^{87}$ i Kielanowski) uważali, że w przypadku wskazań medycznych do przerwania ciąży (np. przy gruźlicy), kobiety powinny mieć dostęp do legalnego zabiegu wykonanego przez zaufanego

\footnotetext{
${ }^{82}$ Odpowiedź ginekologów warszawskich, „Służba Zdrowia” 1957, nr 6, s. 4.

${ }^{83}$ Ibidem.

${ }^{84}$ Podobnie w czasie dyskusji argumentowała także Jolanta Massalska, Druga odpowiedź prof. Kielanowskiemu, „Służba Zdrowia” 1957, nr 11, s. 3.

${ }^{85}$ List otwarty...

${ }^{86}$ T. Kielanowski, Mój życiorys naukowy, „Kwartalnik Historii Nauki i Techniki” 23, 1978, nr 3-4, s. 561-592.

${ }^{87}$ M. Sopek, U. Olańska-Wagilewicz, Lekarze białostoccy: Stanisław Gajewski (1913-1983), Uniwersytet Medyczny w Białymstoku, https://www.umb.edu.pl/medyk/tematy/wspomnienia_i_refleksje/lekarze_bialostoccy:_stanislaw_gajewski_(1913-1983) (dostęp: 29 VI 2017).
} 
lekarza, aby „nie musiały szukać pomocy akuszerek, babek i innych partaczy”88. Interniści zaś zwracali uwagę na los „niechcianych dzieci”, cierpiących fizycznie i moralnie: "głodnych, niekochanych, ginących wśród męczarni" ${ }^{9}$.

Dla sygnatariuszy listu do ginekologów, walka z „babkarstwem” nieprzypadkowo stanowiła istotny kontekst i ważny argument przemawiający za poparciem dla wprowadzonej w 1956 r. ustawy. Pracując w szkołach medycznych powstałych po II wojnie światowej we wschodniej części Polski, Kielanowski czy Gajewski praktykowali na terenach, gdzie ponad dekadę po wojnie profesjonalna medycyna nadal konkurowała z ludowymi praktykami leczniczymi, „babki” zaś powszechnie

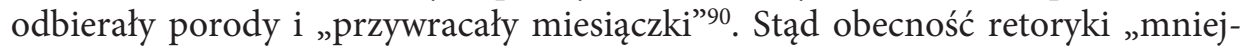
szego zła" w wypowiedziach Kielanowskiego, podkreślającego nierzadko tragiczne konsekwencje nielegalnych zabiegów wykonywanych przez „partaczki”. Porównując błahe według niego konsekwencje zdrowotne mogące wystąpić po legalnej i fachowej aborcji ze zgonem zdesperowanej kobiety, sygnatariusz listu pytał retorycznie, co lepsze: „ryzyko zapalenia przydatków czy śmierć z ręki babki lub w nurtach Wisły" 91 .

W dyskusji z ginekologami warszawskimi, ich oponenci odwoływali się także do kwestii klasowych i do dysproporcji we wpływie kryminalizacji aborcji na różne warstwy społeczne. Wskazywali, że odmowy przerwania ciąży w społecznej służbie zdrowia, w której zatrudnieni byli „ginekolodzy warszawscy”, zmuszały kobiety do „szukania pomocy w gabinetach prywatnych bądź do poddawania się tańszym zabiegom"92. O ile bardziej zamożne pacjentki mogły sobie pozwolić finansowo na prywatne usługi medyczne, to uboższe kobiety „opór” ginekologów skazywał na „babki” i podobną niefachową pomoc. Podkreślając, że „sprawa jest tym boleśniejsza, że krzywdzi niemal wyłącznie kobiety klas mało zarabiających, robotnice, żony robotników i chłopki”93, polemiści ginekologów warszawskich uwypuklali bardzo istotny wymiar klasowy „walki z babkarstwem” i medykalizacji przerywania ciąży w Polsce Ludowej.

Kielanowski polemizował ponadto z koronnym argumentem warszawskich ginekologów o „z reguły” szkodliwym wpływie sztucznych poronień na zdrowie kobiety, podważając tak naprawdę całą obecną w debacie publicznej retorykę o „aborcji jako chorobie”. Zgadzając się, że „przerwanie ciąży może być czasem [wyróżnienie oryg.] przyczyną powikłań i chorób" ${ }^{\text {", }}$, posługiwał się jednocześnie zdroworozsądkowym argumentem odwołującym się do wysokiego przyrostu

\footnotetext{
${ }^{88}$ T. Kielanowski, Jeszcze raz w sprawie przerywania ciąży, „Służba Zdrowia” 1957, nr 8, s. 4.

${ }^{89}$ Ibidem.

${ }^{90}$ A. Malarewicz, M. Sola, op. cit., s. 88.

${ }_{91}$ T. Kielanowski, Piekła kobiet ciag dalszy, „Służba Zdrowia” 1957, nr 13, s. 3.

${ }_{92}$ List otwarty...

${ }^{93}$ Ibidem.

94 T. Kielanowski, Jeszcze raz $w$ sprawie...
} 
naturalnego w powojennej Polsce. Według niego, szacunkowe trzy miliony sztucznych poronień, którym się miały poddać przez dekadę od końca II wojny światowej Polki, nie przeszkodziły w corocznych narodzinach 800 tys. nowych zdrowych obywateli. Przerywające ciąże kobiety, jak w prosty sposób wskazywał Kielanowski, nie stawały się bezpłodne i nie cierpiały „z reguły” na cały szereg schorzeń wymienianych przez warszawskich ginekologów i figurujących w innych, także popularnych, publikacjach ${ }^{95}$.

Wniosek Kielanowskiego jednak nie przedostał się, jak się zdaje, do oficjalnego medycznego dyskursu kierowanego do opinii publicznej, gdzie co najmniej do lat osiemdziesiątych XX w. - jak wskazuje Agata Ignaciuk - dominował prze-

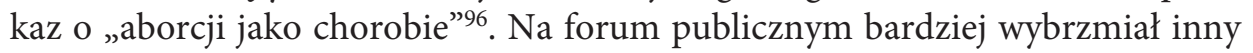
postulat lekarza: propaganda środków i metod zapobiegających niepożądanej ciąży, prowadzona w Polsce Ludowej przez władze i społeczników pod hasłem „świadomego macierzyństwa”. Planowanie rodziny było według Kielanowskiego odpowiedzią na potrzeby i argumenty obu prezentowanych na łamach „Służby Zdrowia” stanowisk. Świadome macierzyństwo powinno według niego zjednoczyć oponentów przerywania ciąży, jak i zwolenników ustawy 1956 r., prowadząc do tego, „by żadna kobieta nie ginęła $z$ winy partaczy i żadna już nie chorowała po zabiegu wykonanym fachowo"97.

Postulowany przez Kielanowskiego oraz wielu innych lekarzy łatwy i powszechny dostęp do bezpiecznych i pewnych środków antykoncepcyjnych nie stał się jednak w Polsce Ludowej rzeczywistością. Pomiędzy oficjalną retoryką, zawartą także w ustawie z 1956 r., i realnymi krokami mającymi na celu ochronę zdrowia reprodukcyjnego kobiet, panował przez całe dziesięciolecia rozdźwięk. Przedkładanie innych (konsumpcyjnych) potrzeb, bariery mentalne oraz trudności zaopatrzeniowe powodowały, że praktycznie przez cały okres trwania PRL kobiety miały duże trudności z dostępem i możliwością korzystania ze skutecznych i nieszkodliwych metod i środków zapobiegania ciąży, powszechnie uważanej za zdrowotnie bardziej preferowaną metodę unikania niepożądanego potomstwa ${ }^{98}$. W wielu warstwach i środowiskach społecznych sztuczne poronienia, pomimo oficjalnej medycznej narracji o „przerywaniu ciąży jako chorobie”, stanowiły

\footnotetext{
95 T. Kielanowski, Piekła kobiet...

${ }^{96}$ A. Ignaciuk, „Ten szkodliwy zabieg”...

${ }_{97}$ T. Kielanowski, Jeszcze raz w sprawie..., s. 4.

${ }^{98} \mathrm{Na}$ temat stosunku kobiet wiejskich do antykoncepcji por. np.: E. Szpak, „Chory człowiek jest wtedy jak coś go boli". Społeczno-kulturowa historia zdrowia i choroby na wsi polskiej po 1945 r., Warszawa 2016, s. 238.
} 
główną metodę regulacji urodzeń. Według niektórych badaczy, w Polsce Ludowej panowała nawet „kultura aborcji”, charakteryzująca się preferencją dla przerywania ciąży jako metody planowania rodziny ${ }^{99}$. Przyczyniły się do tego faktu m.in. czynniki finansowe i medyczne: bezpłatność zabiegów sztucznych poronień w społecznej służbie zdrowia, alternatywa dla szpitalnej aborcji w postaci prywatnych gabinetów lekarskich, niesubsydiowanie środków antykoncepcyjnych, słaby dostęp do nowoczesnych metod zapobiegania ciąży ${ }^{100}$. Medykalizacja aborcji polegająca na jej patologizacji i przedstawianiu jako choroby odniosła więc sukces tylko na poziomie retoryki, nie wpływając, jak się zdaje, w dużym stopniu na praktyki reprodukcyjne kobiet. Po liberalizacji ustawy z 1956 r. liczba sztucznych poronień była szacowana na $300-700$ tys. rocznie ${ }^{101}$. Na poziomie od ok. 300 do ok. 500 tys. utrzymywała się przez lata sześćdziesiąte i siedemdziesiąte XX w., po dalszej liberalizacji prawodawstwa i wprowadzeniu praktycznie „aborcji na życzenie” 102 .

$\mathrm{W}$ długiej perspektywie zrealizowany został z kolei postulat medykalizacji sztucznych poronień na pierwszym z opisywanych przeze mnie poziomów: objęcia przerywania ciąży, a także innych praktyk reprodukcyjnych kobiet, kontrolą lekarza. Nie był to jednak szybki i łatwy proces, widać w jego przypadku także kilka paradoksów. W pierwszych latach po wprowadzeniu ustawy liczba niezmedykalizowanych, nielegalnych poronień wywoływanych przez kobiety czy też „babki” była wciąż wysoka i utrzymywała się na tym samym poziomie co przed $1956 \mathrm{rr}^{103}$ Nadal ok. 80 tys. kobiet przyjmowano do szpitala z rozpoczętym poza nim poronieniem. W 1959 r. liczbę aborcji oceniano na przywoływane 300-700 tys. rocznie $^{104}$. Sama skala rozbieżności w szacunkach wskazuje, że przerywanie ciąży w małym stopniu znajdowało się pod kontrolą środowiska lekarskiego.

Jednocześnie, ustawa z 1956 r. mogła paradoksalnie przyczynić się do większej medykalizacji innych aspektów zdrowia reprodukcyjnego Polek. Wskazują na to przykładowo dane z Gdańska z 1958 r. dotyczące opieki nad kobietą w ciąży. Sprawozdający na ich temat urzędnik podkreślał, że największy odsetek ciężarnych

${ }_{99}$ L. Stloukal, Understanding the „Abortion Culture” in Central and Eastern Europe, w: From Abortion to Contraception, ed. H.P. David, London 1999, s. 23-38.

${ }^{100} \mathrm{Na}$ temat ostatniego z tych czynników por.: A. Ignaciuk, „Clueless about Contraception”. The Introduction and Circulation of the Contraceptive Pill in State-socialist Poland (1960s-1970s), „Med Secoli” 26, 2014, nr 2, s. 509-535.

101 AAN, MZ, sygn. 1/47, Informacja o wykonaniu ustawy o warunkach dopuszczalności przerywania ciąży oraz realizacji zarządzeń w sprawie jej zapobiegania, k. 491.

102 M. Okólski, Abortion and Contraception in Poland, „Studies in Family Planning” 14, 1983, nr 11, s. 266.

${ }^{103}$ AAN, MZ, sygn. 1/37, Protokół nr 35/58 posiedzenia Kolegium Ministerstwa Zdrowia w dniu 29 października 1958 we Wrocławiu, k. 26; S. Pogoda, Sprawa Anny Nowak, „Służba Zdrowia” 1958 , nr 15, s. 4.

${ }^{104}$ AAN, MZ, sygn. 1/47, Informacja o wykonaniu ustawy..., k. 491. 
(38\%) odwiedza lekarza w pierwszym trymestrze. Dla dwóch kolejnych wielkości te wynosiły odpowiednio 29 i 33\%. Komentujący te rozbieżności wskazywał, że: „większy odsetek zgłaszania się do opieki w okresie do 3 miesięcy wiąże się ze zwiększonym zapotrzebowaniem na poradnictwo w zakresie przerywania ciąży"105.

„Spędzanie płodu” przez niewykwalifikowane akuszerki i kryminalne aborcje na większą skalę wyeliminowała dopiero nowelizacja ustawy o warunkach przerywania ciąży z końca 1959 r. Zmieniała ona te elementy prawodawstwa, które przyczyniały się do ciągłego poszukiwania pokątnych usług nieprofesjonalnych praktyków medycznych. Przede wszystkim, według nowego ustawodawstwa lekarz przestał być osobą decydującą o wskazaniach do przerwania ciąży. Zniesiono przepis, że specjalista wystawiający orzeczenie do zabiegu sam nie może wykonać interrupcji. Aborcję można było od tego czasu przeprowadzić ambulatoryjnie, a nie tylko w szpitalu. W następnych latach i dekadach rosła również liczba zabiegów dokonywanych $\mathrm{w}$ gabinetach prywatnych. Aborcje te miały być obowiązkowo zgłaszane do celów statystycznych.

To formalne pozbawienie lekarzy możliwości decydowania o przerywaniu ciąży stało się paradoksalnie krokiem w kierunku praktycznie kompletnej medykalizacji aborcji w Polsce Ludowej. Dostęp do bezpłatnych sztucznych poronień spowodował koniec ery „babek” i przeniesienie zabiegów do szpitali i gabinetów prywatnych, czyli pod kontrolę środowiska lekarskiego. Skutkiem ten zmiany była coraz mniejsza liczba kryminalnych poronień, samobójstw kobiet w niechcianej ciąży, dzieciobójstwa czy też zmniejszenie się liczby zgonów kobiet w związku z pokątnie dokonaną aborcją ${ }^{106}$. „Walka z babkarstwem” o życie kobiet została przez socjalistyczną medycynę bezsprzecznie wygrana. Nie oznacza to jednak, że zmedykalizowane aborcje wykonywane w szpitalach po 1959 r. były zawsze bezpieczne dla zdrowia żeńskiej części społeczeństwa. Powikłania, o których na kartach swoich publikacji pisali ginekolodzy, w wielu przypadkach związane były $\mathrm{z}$ metodą przerywania ciąży stosowaną $\mathrm{w}$ społecznej służbie zdrowia aż do 1989 r. Metoda łyżeczkowania niosła ze sobą niebezpieczeństwo przebicia macicy i stanowiła większe zagrożenie dla zdrowia kobiety niż zastosowanie próżnociągu, od lat siedemdziesiątych XX w. używanego w krajach zachodnich. Próżnociąg, który do przerwania ciąży przystosowano i następnie testowano w Chińskiej Republice Ludowej, wprowadzono jako główną metodę aborcji m.in. w Czechosłowacji. Nie był on więc technologią nieznaną i nieobecną w krajach socjalistycznych. Jak podkreśla ponadto Andrzej Kulczycki, w PRL zabieg

${ }^{105}$ AAN, MZ, sygn. 1/42, Referat o stanie zdrowia ludności, o bazie materialnej i pracy służby zdrowia województwa gdańskiego, Gdańsk kwiecień 1959, k. 317.

${ }^{106}$ M. Okólski, op. cit., s. 226. Spadek liczby zgonów spowodowanych kryminalnymi poronieniami zaobserwowano już $\mathrm{w}$ drugiej połowie lat pięćdziesiątych jeszcze przed nowelizacją ustawy. Według Jana Lesińskiego, liczba śmierci kobiet, które z powodu (sztucznego) poronienia zmarły w szpitalu zmniejszyła się z 76 w 1956 r. do 26 trzy lata później; J. Lesiński, op. cit., s. 18. 
przerywania ciąży wykonywano czasami (podobnie jak w Związku Radzieckim) bez znieczulenia ${ }^{107}$. Te dwa ostatnie fakty poddają poważnie w wątpliwość deklaracje o większym bezpieczeństwie, jakie miała kobietom w Polsce zapewnić ustawa z kwietnia 1956 r. Zabiegi przerywania ciąży bez znieczulenia przywodzą $\mathrm{z}$ kolei na myśl totalitarne praktyki porodowe w Polsce Ludowej i na przełomie lat osiemdziesiątych i dziewięćdziesiątych XX w. ${ }^{108}$ Odsłaniają one inne oblicze doświadczeń reprodukcyjnych kobiet w placówkach socjalistycznej medycyny: dyscyplinujących, uprzedmiotawiających, nacechowanych paternalistycznym stosunkiem lekarzy do pacjentek, które znajdowały się pod kontrolą medyków posiadających profesjonalną wiedzę i władzę. W obrazie tym brakuje oddolnych ruchów społecznych na rzecz zdrowia reprodukcyjnego kobiet, funkcjonujących ówcześnie w państwach zachodnich, a nieobecnych w niedemokratycznych krajach bloku wschodniego. Sprzeczności pomiędzy oficjalną retoryką i rzeczywistymi praktykami pokazują także potrzebę kompleksowych badań nad doświadczeniami reprodukcyjnymi kobiet w PRL, nie tylko w odniesieniu do ich relacji z „babkami” czy środowiskiem profesjonalnych ginekologów.

\section{Fight with granny midwives over women's health: the medicalisation of abortion in socialist Poland (1950s and 1960s) (Abstract)}

In 1956 the communist state authorities liberalized the anti-abortion law that the Polish People's Republic inherited from the interwar period. Using the rhetoric of women's health and framing their decision as a safety measure, the legislators intended to curb the high number of clandestine abortion procedures performed outside the realm of socialist medicine. As I argue in my paper, in the official political and medical discourse abortion legislation passed in Poland in the 1950s constituted an element of the war against traditional medicine which was waged by the authorities of socialist Poland. One of the targets of this fight were "granny midwives": traditional folk female healers who were helping peasant women in many aspects of their reproductive lives and who were customarily accused of performing high numbers of criminal abortions. Thus it was against these "granny midwives" that the socialist state had to fight over the life and health of Polish women. Presenting abortion as an intricate medical procedure whose success depended on the skills of a highly qualified and experienced personnel, socialist doctors and authorities did not only medicalise abortion, but also pathologised it, depicting the termination of a pregnancy as a disease requiring the care of a professional medical practitioner. What was also at stake at the fight against "granny midwives" was the shift from pre-modern, traditional healing practices to modern, scientific medicine that was regarded as a tenet of state socialism.

107 A. Kulczycki, Abortion Policy in Postcommunist Europe: The Conflict in Poland, „Population and Development Review" 21, 1995, nr 3, s. 476.

108 A. Wochna-Tymińska, Zakład produkcji dzieci. Oddział położniczy w Polsce przełomu lat osiemdziesiątych i dziewięćdziesiątych XX w., w: Kłopoty z seksem..., s. 187-239. 


\section{Bibliografia}

\section{Źródła archiwalne}

\section{AAN, MZ}

sygn. 1/27, Stan opieki położniczej i ginekologicznej w kraju i wytyczne na przyszłość, $1956 \mathrm{r}$. sygn. 1/37, Protokół nr 35/58 z posiedzenia Kolegium Ministerstwa Zdrowia w dniu 29 października 1958 we Wrocławiu

sygn. 1/42, Referat o stanie zdrowia ludności, o bazie materialnej i pracy służby zdrowia województwa gdańskiego, Gdańsk, kwiecień 1959

sygn. 1/47, Informacja o wykonaniu ustawy o warunkach dopuszczalności przerywania ciąży oraz realizacji zarządzeń w sprawie jej zapobiegania

\section{Źródła drukowane}

Beaupré J., Jak zapobiegać ciąży, Warszawa 1959

Bulski T., Poradnik małżeński, Warszawa 1962

Chrościcki, A., Matka tysiąca dzieci. Wspomnienia o Emilii Paderewskiej-Chrościckiej, Warszawa 2001

Gabler W., Janczewski Z., O przerywaniu ciąży, Warszawa 1957

Kwiatkowski M., Sprawy życia i sprawy śmierci, Warszawa 1956

Lesiński J., Zarys zapobiegania ciąży. Dla lekarzy i studentów medycyny, Warszawa 1961

Majle T., Co każde małżeństwo wiedzieć powinno o zapobieganiu ciąży, Warszawa 1958

Pumpiański R., Higiena w życiu kobiety, Warszawa 1956

Pumpiański R., Jak zapobiegać ciąży, Warszawa 1957

Warunki dopuszczalności przerywania ciąży, Warszawa 1959, wyd. 2

Zdrowie kobiety, red. J. Lesiński, R. Pumpiański, Warszawa 1957

\section{Opracowania}

Bołdyrew A., Matka i dziecko w rodzinie polskiej. Ewolucja modelu życia rodzinnego w latach 17951918, Warszawa 2008

Brodie J.F., Contraception and Abortion in 19th-century America, Ithaca and London 1994

Czajkowska A., O dopuszczalności przerywania ciąży. Ustawa z dnia 27 kwietnia 1956 r. i towarzyszace jej dyskusje, w: Kłopoty z seksem w PRL. Rodzenie nie całkiem po ludzku, aborcja, choroby, odmienności, red. M. Kula, Warszawa 2012

Engelstein L., The Keys to Happiness. Sex and the Search for Modernity in Fin-de-Siècle Russia, Ithaca and London 1992

Fidelis M., Kobiety, komunizm i industrializacja w powojennej Polsce, tłum. M. Jaszczurkowska, Warszawa 2015

Fisher K., Birth Control, Sex, and Marriage in Britain 1918-1960, Oxford and New York 2008

Gawin M., Planowanie rodziny - hasła i rzeczywistość, w: Równe prawa i nierówne szanse. Kobiety $w$ Polsce międzywojennej, red. A. Żarnowska, A. Szwarc, Warszawa 2000

Childbirth. Changing Ideas and Practices in Britain and America 1600 to the Present, t. 2: The Medicalization of Obstetrics. Personnel, Practice, and Instruments, ed. P.K. Wilson, New York and London 1996

Ignaciuk A., "Clueless about Contraception”. The Introduction and Circulation of the Contraceptive Pill in State-socialist Poland (1960s-1970s), „Med Secoli” 26, 2014, nr 2

Ignaciuk A., „Ten szkodliwy zabieg”. Dyskursy na temat aborcji w publikacjach Towarzystwa Świadomego Macierzyństwa / Towarzystwa Planowania Rodziny (1956-1980), „Zeszyty Etnologii Wrocławskiej" 20, 2014, nr 1

Jaguś I., Lecznictwo ludowe w Królestwie Polskim na przełomie XIX i XX w., Kielce 2002 
Kligman G., Polityka obłudy. Kontrola rozrodczości w Rumunii pod rządami Ceausescu, tłum. P. Art, Kraków 2010

Klich-Kluczewska B., Rodzina, tabu i komunizm w Polsce 1956-1989, Kraków 2015

Klich-Kluczewska B., Making up for the Losses of War. Reproduction Politics in Post-War Poland, $\mathrm{w}$ : Woman and Man at War. A Gender Perspective on World War II and its Aftermath in Central and Eastern Europe, ed. M. Roger, R. Leiserowitz, Osnabruck 2012

Klich-Kluczewska B., Przypadek Marii spod Bochni. Próba analizy mikrohistorycznej procesu o aborcję z 1949 r., „Rocznik Antropologii Historii” 2, 2012, nr 1(2)

Kościańska A., Płeć, przyjemność i przemoc. Ksztattowanie wiedzy eksperckiej o seksualności w Polsce, Warszawa 2014

Kuklo C., Czy społeczeństwo polskie w dobie Oświecenia regulowało liczbę dzieci w rodzinach?, „Roczniki Dziejów Społecznych i Gospodarczych" 51-52, 1990/1991

Kulczycki A., Abortion Policy in Postcommunist Europe: The Conflict in Poland, „Population and Development Review" 21, 1995, nr 3

Kurkowska M., „Fabrykantki aniołków”. O problemie aborcji w Polsce w latach 1878-1939, „Arcana” 19, 1998, nr 1

Kuźma-Markowska S., Międzynarodowe aspekty działalności Towarzystwa Świadomego Macierzyństwa w latach 50. i 60. XX w., w: Problem kontroli urodzeń i antykoncepcji. Krytyczno-porównawcza analiza dyskursów, B. Płonka-Syroka, A. Szlagowska, Wrocław 2013

Kuźma-Markowska S., From „Drop of Milk” to „Bureaus for Mothers”. Infant Care and Visions of Medical Motherhood in the Early 20th Century Polish Part of the Habsburg Empire, w: Medicine Within and Between Habsburg and Ottoman Empires, 18th-19th Centuries, ed. D. Sechel, Bochum 2012

Leavitt J.W., "The Growth of Medical Authority" Technology and Morals in Turn-of-the-Century Obstetrics, w: Women and Health in America. Historical Readings, ed. J.W. Leavitt, Madison, Wisconsin 1999

Lee E., Abortion, Motherhood, and Mental Health. Medicalizing Reproduction in the United States and Great Britain, New York 2003

Libera Z., Znachor w tradycjach ludowych i popularnych XIX-XX w., Wrocław 2003

Malarewicz A., Sola M., Położnictwo. Miniona Epoka. Przyczynek do historii położnictwa, „Studia Medyczne" 23, 2011, nr 3

McLaren A., A History of Contraception. From Antiquity to the Present, Oxford 1990

Meskus M., To Exclude or to Enclose. Medicalization of Abortion in Finland, 1900-1950, „Scandinavian Journal of History" 30, 2005, nr 1

Miernik G., Wokół ustawy aborcyjnej z 1956 r., w: Zdrowie i choroba. Wpływ jakości życia na kulturę $w$ Europie Środkowej, red. A. Barciak, Katowice-Zabrze 2013

MohrJ.C., Abortion in America. The OriginsandEvolution of National Policy, Oxfordand New York 1979.

Mysztor J., Prawnospołeczne aspekty zabójstw dzieci narodzonych i aborcji na Śląsku w latach 17751914, „Roczniki Nauk Prawnych” 24, 2014, nr 4

Nakachi M., Liberation without Contraception? The Rise of the Abortion Empire and Pronatalism in Socialist and Postsocialist Russia, w: Reproductive States. Global Perspectives on the Invention and Implementation of Population Policy, ed. R. Solinger, M. Nakachi, New York and Oxford 2016.

Okólski M., Abortion and Contraception in Poland, „Studies in Family Planning” 14, 1983, nr 11

Piątkowski W., Spotkania z inną medycyną, Lublin 1990

Randall A.E., „Abortion will deprive you of happiness!” Soviet Reproductive Politics in the Post-Stalin Era, „Journal of Women's History” 23, 2011, nr 3

ReaganL., WhenAbortion WasaCrime. Women, Medicine, and Lawin the UnitedStates, ChapelHill 1997.

Riddle J.M., Eve's Herbs. A History of Contraception and Abortion in the West, Cambridge and London 1997 
Solomon S.G., The Demographic Argument in Soviet Debates over the Legalization of Abortion in the 1920s, „Cahiers du monde russe et soviétique” 33, 1992, nr 1

Stloukal L., Understanding the „Abortion Culture” in Central and Eastern Europe, w: From Abortion to Contraception, ed. H.P. David, London 1999

Szpak E., „Chory człowiek jest wtedy jak coś go boli”. Społeczno-kulturowa historia zdrowia i choroby na wsi polskiej po 1945 r., Warszawa 2016

Szpak E., Pojęcie zdrowia, choroby i cielesności w wiejskim postrzeganiu świata po 1945 roku, czyli o zmianach mentalności na wsi polskiej, „Rocznik Antropologii Historii” 2, 2012, nr 1(2)

Titkow A., Poland, w: From Abortion to Contraception. A Resource to Public Policies and Reproductive Behavior in Central and Eastern Europe from 1917 to the Present, ed. H.P. David, Westport, Connecticut 1999

Usborne C., Cultures of Abortion in Weimar Germany, New York and Oxford 2007

Waszyński E., Historia położnictwa i ginekologii w Polsce, Wrocław 2000

Wochna-Tymińska A., Zakład produkcji dzieci. Oddział położniczy w Polsce przełomu lat osiemdziesiątych i dziewięćdziesiątych XX w., w: Kłopoty z seksem $w$ PRL. Rodzenie nie całkiem po ludzku, aborcja, choroby, odmienności, red. M. Kula, Warszawa 2012

Woycke J., Birth Control in Germany, 1871-1933, New York and London 1988

Więckowska E., Lekarze jako grupa zawodowa w II Rzeczypospolitej, Wrocław 2004

Zielińska E., Between Ideology, Politics, and Common Sense. The Discourse of Reproductive Rights in Poland, w: Reproducing Gender. Politics, Publics, and Everyday Life after Socialism, ed. S. Gal, G. Kligman, Princeton, NJ 2000

Zielińska E., Oceny prawnokarne przerywania ciąży. Studium porównawcze, Warszawa 1986

Zielińska E., Przerywanie ciąży. Warunki legalności w Polsce i na świecie, Warszawa 1990

Sylwia Kuźma-Markowska, dr, historyczka i amerykanistka, adiunkt w Ośrodku Studiów Amerykańskich Uniwersytetu Warszawskiego; absolwentka studiów doktoranckich w Szkole Nauk Społecznych przy IFiS PAN. Zainteresowania naukowe: historia społeczna i kulturowa Stanów Zjednoczonych i Polski w XX w., zwłaszcza historia kobiet i społeczna historia medycyny.

Kontakt: s.kuzma@uw.edu.pl 